\title{
Prosperity in Crisis and the Longue Durée in Africa
}

It is a large subject, because the instrument of change is the human imagination. It changes not only the consoling plot, but the structure of time and the world -Frank Kermode (2000, 31).

This paper uses data from research in Kenya and Zambia to discuss the relationship between rural life and various representations and experiences of it. The research literature on rural Africa is very rich, but understanding the changing nature of rural life in Sub-Saharan Africa over time is not merely a matter of pursuing empirical investigation. As an object of study 'rural life' is a far from self-evident category and its changing character not a matter of straightforward chronology. Africa is a huge continent and the particularities and circumstances of each case are fundamental and binding, but what stands out is the fact that over long periods of time, rural Africa has often been portrayed as in crisis - a genuine crisis of resource and opportunity, and a rather more constructed one of agricultural production and social relations.

The exact nature of this crisis has varied temporally and spatially, but its underlying motif has been one of failed prosperity. From the earliest attempts by colonial governments to extract labour and tax from rural areas to more recent anxieties about agricultural productivity, structural transformation and deagrarianisation, rural life has been found wanting. It has also, rather schizophrenically, and often simultaneously, been portrayed, as the solution to the failures of African prosperity more generally, providing potential economic and social safety nets when other hoped for transformations failed to materialise (World Bank 2007). As a new debate on prosperity begins to take hold in the context of the aftermath of the 2008 crisis, climate change and the emerging post-growth agenda (Jackson 2017; Moore 2015), it is instructive to revisit the particular articulations of crisis and failed prosperity that have shaped intervention, governance, aspiration and transformation in Sub-Saharan Africa.

Recent revisions of the term prosperity have emphasised that it is not just a matter of wealth or income, but a larger terrain encompassing health, well-being, opportunity and quality of life. This enlarged notion of prosperity is increasingly part of policy aspirations in both the global north and the global south (OECD, 2017; Legatum Institute 2017; Social Progress Imperative 2017; Moore and Woodcraft 2018), and replaces - at least for some - a determined emphasis on GDP growth as the measure of economic success, as opposed to a broader emphasis on quality of life (Fioramonti 2017; Hepburn et al. 2014; Philipsen 2017). However, while there is much talk recently of inclusive growth in relation to Africa, both research and policy still focus, for the most part, on high levels of GDP growth as the way out of crisis (World Bank 2016; Adam, Collier, and Ndung'u 2011; Adam, Collier, and Gondwe 2014). In this article, I discuss how a continued focus on growth as the headline indicator for economic success perpetuates policy interventions that fail to recognize the real nature and character of structural transformation in Africa.

In particular, I discuss how visions of future prosperity based on standard models of agrarian transformation have failed to materialize because they have focused on agricultural productivity and market integration at the expense of quality of life and ecological well-being. Understanding the evolution and tenacity of particular ways of envisaging economic growth and development for Africa requires a form of analytical history that examines how conceptual structures function over the longue durée. Such an approach is more than simply empirical analysis through time or a set of abstractions based on the selfunderstandings of historical agents. It involves the development of a hypothetical analytic 
structure which through its own forms of transformation eventually comes to play a role in shaping the lived world of participants, including researchers, policy makers and ordinary citizens (Moore and Vaughan 1994). The effects of such transformations are often partial and incomplete, even contradictory, but they are of immense significance because of their entanglements with power and politics. Braudel's ([1949] 1995) original conceptualization of the longue durée emphasized both the plurality of historical temporalities, and the significance of geography and the environment for historical analysis. His call was for disciplines to work collectively ([1958] 2009). Braudel proffered various formulations of the longue durée, including the geometric space of western painting and the language of financiers ([1958] 2009, 179-180;190-191). His point being that the longue durée is a methodological tool suitable for the analysis of particular problems rather than a theory in and of itself. He insisted on understanding the long run structures of the economy, the continuities that exist between the present and the past which shape the character, flow and possibilities of people's lives without necessarily being apparent to them. Braudel was interested not just in capitalism, but in the economy understood as culture, as 'old habits of thought and action, of frameworks that strenuously resist dying, however illogical' ([1958] 2009, 180). How long such frameworks could endure varied according to Braudel, but the principle was that by tacking back and forth from structure to data those limits could be determined ([1958] $2009,195)$. For Braudel history was a science and its purpose was to help us understand the present.

My aim in this article is thus to demonstrate how a long running - but temporally and spatially variable - focus on agricultural productivity has shaped the character of rural life in Africa, and why it has consistently failed to deliver enlarged forms of prosperity based on quality of life and ecological well-being. I am not concerned here with theorizing Braudel or with different kinds of historical temporalities (longue durée $\mathrm{v}$ conjoncture $\mathrm{v}$ événement), but rather with exploring how a long run structure helps us in understanding rural Africa over the last 100 years. My own research history has been bound up with two different experiences of studying long term change. Megan Vaughan and I studied Bemba agriculture in the Northern Province of Zambia over a hundred year period from 1890-1990 based on a restudy of Audrey Richards's original work on land, labour and diet in the 1930s (Moore and Vaughan 1994; Richards 1939). In Kenya, I have been studying the same village in Elgeyo-Marakwet County since 1980, exploring changes in livelihoods, gender relations, rituals and environmental management (Davies and Moore 2016; Moore 1996).

The Kenyan and Zambian cases are exemplars not only of the historical and structural origins of rural crisis, but of the frameworks used both to create and manage that crisis. The Bemba of the Northern Province provided the labour for the mines on the Copperbelt, linking agricultural production to migration, wage labour, extractive mining and world commodity prices. Elgeyo-Marakwet in northern Kenya was also a native reserve in the colonial period, and markets of all kinds, but most especially in land, came only tardily. The Bemba were drawn from the land by the industrial labour requirements of the colonial state, and the Marakwet were largely tied to it by restrictions on movement. They provide different ideas about what the rural has meant and means in some contexts in Sub-Saharan Africa, and allow some reflection on the more general proposition that Africa's crisis as locally produced and experienced by rural residents, as a feature of development, as an imperative for governance, and as a framework for research has much to do with the temporal and spatial images of the world we derive 
from our categories. It is also, and more importantly, the material consequence of the way successive generations have conceived of economic success, at the expense of social and ecological well-being.

\section{The Creation of a Rural World in Crisis}

'What can be thought must certainly be a fiction' -Nietzsche $(1968,291)$. In saying this, Nietzsche had in mind thought's limitations in relation to world. Thinking about the character and future of the rural world in Africa impressed upon me anew the fact that we impose patterns on historical time. What is evident is that for all social scientists, time has to be 'more than one damned thing after another' as Kermode would have it (2000, 47 ), and history as a human project can never be mere chronicle because it ignores whatever is not concordant (51). In social theory, as in other domains of life, we cannot humanise time without also humanising space. Many of our models of sociality, social change, and processes of transformation seek to do just that, they create categories within which we can work: village, peasant, clan, woman-farmer, an MSM (a man who has sex with men) (Moore 2011, 77-105). Such categories are often also the building blocks of governance and social policy, directing financial flows both in the form of inward transfers (aid budgets, cash transfers, agricultural subsidies) and of extractions (taxes etc.). Such categories are ways of cutting up the world to make it intelligible, but are also the product of imaginative structurings with their own material realities over time. In the case of rural Sub-Saharan Africa, these material realities have been bound up since colonial times with the crisis of peasant agriculture, its failing productivity and its debilitated prosperity. Colonial and post-colonial governments, aid agencies and international development policy have all refigured the dream of the prosperous peasant. In this sense, modern Africa - like anywhere else - is the consequence of human design on the world. However, these categories of design are not things that lie outside the observer and just wait to be found, if Kermode is to be believed, they are also things that we need both emotionally and intellectually as residents, researchers and rulers. But how do these productive fictions coincide with reality? Science and social science alike depend on the "Necessary relation between the fictions by which we order our world and the increasing complexity of what we take to be the 'real' history of that world' (Kermode 2000, 67). Fictions and world coincide to a certain extent, but we also know that we cannot easily distinguish between a fact and our knowledge of the fact, for merely establishing facts inevitably links them to concepts (Moore and Vaughan 1994, xii-xxv). We must acknowledge the historicity of facts, and while our personal satisfactions in science and in life demand a degree of compliance with reality as we imagine it, the questions and categories with which we begin, are the stuff of human engagement and imagination, and not that of nature. As Whitehead remarked 'Nature is patient of interpretation in terms of laws that happen to interest us' $(1967,136)$.

Why does a sense of crisis pervade in relation to rural Africa? Partly perhaps, as Kermode suggests, because there is a resistance to 'humanly uninteresting successiveness' $(2000,46)$, and partly because of Africa's relation to the imaginative structuring of time and in particular that form of time that has perhaps been most important for representations of Africa, developmental time - the time of progress or rather the crisis of its lack. Visions of modernity, as Jameson suggests, feed on notions of crisis, and tend to 'project an idea of the historical period as massive homogeneity (bounded on either side by inexplicable chronological metamorphoses and punctuation marks)' (1991, 55-56). As Latour puts it '[t] he adjective 'modern' designates a new regime, an acceleration, a rupture, a revolution in time. When the word 'modern,' 
'modernization,' or 'modernity' appears, we are defining, by contrast, an archaic and stable past. Furthermore, the word is always being thrown into the middle of a fight, in a quarrel where there are winners and losers, Ancients and Moderns. 'Modern' is thus doubly asymmetrical: it designates a break in the regular passage of time, and it designates a combat in which there are victors and vanquished' $(1993,10)$. The point both make is that historical periodization - where differences and non-linear features are subsumed - is implicit in categorisations, and even when criticised or repressed threatens to break into our forms of thought. Theories of crisis are the inevitable consequence of the entanglements of periodizations and categorisations because transformations require rupture. In relation to rural Africa, the ideas, arguments and policies concerning the nature of its residents (modern peasants or traditional farmers), its economy (market oriented or kinship focussed), and its potentialities (productive asset or backwater) have insistently referred to intertwined imaginings of time, place and categorisations.

The rural world of Sub-Saharan Africa was not a pre-existing empirical entity or category, but something that had first to be specified in time and place. African societies were by definition non-European societies at a different stage of development. The requirements of colonial governance involved two contradictory processes: the first was to transform rural life and the second was to safeguard it in its structures and traditions. Bringing large sections of a vast continent, with its differing societies, forms of governance, networks of connection and productive possibilities under the thin crust of colonial government was inevitably a variegated and uncertain process. The sparsely populated areas of Zambia and Kenya, looked nothing like the rural areas of England, but they had to be imaginatively and productively transformed into spaces that could turn out labour and tax. Agricultural productivity was at the heart of this dilemma. It needed to be maintained to guarantee food supplies, but also to sustain what were seen as ideally selfsufficient traditional societies. However, the colonial authorities needed labour - partly for infrastructure projects and later for successful settler agriculture - and labour provided workers with money to pay taxes. The result was a contradiction at the heart of colonial rural policy: how to change a society and its productive system, and yet keep it the same. As early as 1901, the British South Africa Company official in charge of the Mpika station in Northern Rhodesia (Zambia) was caught in the dilemma of how to balance food production and labour requirements. He frequently found himself without labour because people were working in their gardens or with no work to offer and only half the taxes collected. He could not afford to jeopardise the production of food in the area through forcible labour recruitment, and was also in competition with the local Chiefs who viewed his demands on labour as rivalling their own. This turned out to be symptomatic of the situation for decades to come (Moore and Vaughan 1994, 12).

The management of agriculture and labour was a key part of colonial governance, but it was also responsible for a reconfiguration of the landscape into different categories. Key to this process was control over people's movement. The insistence that 'native peoples' reside for the most part on land reserved for them reinforced particular understandings of the relationship between identities and productive systems. Anthropologists played an important role in documenting and consolidating such linkages, creating tribal societies with particular ways of life and modes of livelihood. However, from the very beginning of colonial rule anxieties were expressed about what were termed 'scattered settlements' and forms of 'shifting cultivation'. In the first decades of colonial rule, as Deborah Bryceson has noted 'the wide variety of forms of African clans, lineages and age-grade systems which had functioned as flexible social organizations for facilitating territorial 
movement and minimizing risk connected with shifting cultivation were being eroded. Pressure was being exerted on the dispersed loyalties and rights and obligations of individuals within lineage structures to consolidate and concentrate loyalties within household units where production, consumption and reproduction activities' could intersect in ways that were comprehensible to those running systems of governance whether of the economy or the soul (Bryceson 2000, 45).

Central to this process were the imposition of hut and poll taxes which forced rural producers to earn cash for tax payment, generating the foundations for the continent's agricultural export economy and its industrial development. The Bemba went to the mines and the Marakwet to the highlands to work for White farmers. Taxation involved identifying a 'head of household' as the taxpayer, which encouraged the strengthening of more insular household relations, and coupled with a growing cash economy in some regions led to changing ideas of property ownership and smaller households compared with larger collective units. In order for tax to be collected, chiefs and headmen had to function, and where they did not exist, as in Elgeyo-Marakwet, both they and the units over which they were supposed to have control, notably villages, had to be created. Villages in Marakwet were not a local category, and neither were the chiefs and the headmen who had to be created to run the villages and collect the tax. Even today, Chiefs have difficulty actually controlling their populations because within a local political system based on rule by male elders, they are, at best, primus inter pares. The result of the creation of traditional authorities was that villages were nested within tribes. Tribes remained the ultimate organising unit both of research and governance, but villages acted as strategic points of entry, a way of delimiting the complexities of settlement and sociality as they spread out across the landscape. For anthropology, its' study of kinship had to have a locale, a way of drawing boundaries around what was being studied, deciding who was in and who was out, with the result that much anthropology of the period between the 1940s and the 1970s in Africa struggled to make formal kinship models coincide with forms of lived settlement and sociality. But, the fact of the matter was that village life in the sense that was being sought had never existed for the vast majority of the Bemba speaking peoples. In the northern province of Zambia, ties were to people and to territories, rather than to villages per se (Moore and Vaughan 1994, page number?). Villages were not indigenous to other parts of Zambia either. Long term research in Gwembe, in the southern province, documents neighbourhoods based on groupings of related families and collective ritual activities, cross-cut by matrilineal clans, which preceded colonial transformations and persist to the present (Cliggett 2001). The Gwembe Tonga were displaced into villages in the 1950s which then disintegrated when many people moved to open up new lands near the Kafue Reserve in the 1980s, and have since been reconsolidated to a certain extent after further devolution of power to local headmen in the 1990s made them conduits for food aid distribution and other state resources (Cliggett 2000; Cliggett et al. 2007). Villages come and go, but what is clear is that they were not in the past, and are not now, the only, or even the major, way of organising the key ecologies of productivity, knowledge and resource on which people depend.

But, even if the village was not necessarily the horizon of either sociality, or of meaning making, for the residents of the northern and southern provinces of Zambia, it was a spatial and temporal category essential to the problem of how to conceive of governance and development because the notion of the rural which came to characterise the Africa landscape was one of populations characterised as village dwellers. Up until the 1940s in 
Zambia, the colonial government required people to reside within a registered village (Moore and Vaughan 1994, 111), and in the first decade of Independence (1964-74), village regrouping, as it was called, was a central tenet of rural development policy (Bratton 1980, 125; Berry 1993). In different historical periods, the non-existence of the village or rather its ability to appear and disappear has produced a sense of rural life in crisis. In the Northern Province of Zambia, colonial reports from the 1930s onwards take on an almost biblical tone, speaking of male labour migration to the Copperbelt in terms of exodus. The spectre was of ruined villages, deracinated male 'natives' and the breakdown of traditional society. Anthropologists from the 1930s to the 1960s were extremely anxious about what they termed 'detribalisation' and the impact of modern economies and urban living on traditional ways of life (Moore and Vaughan 1994, 140). The result was a view that the underdevelopment of tribal areas was due to the disintegration of village life, and that the depredations of modernity were causing a crisis in the character and reproduction of the social realm. A view reproduced by successive governments well after Independence and beyond. The possibility that rural life and livelihoods in the Northern Province depended on scattered settlement was no more acceptable to post-Independence governments than it had been to the Colonial authorities (Moore and Vaughan 1994, 136-137). What was particularly strange about this concerted effort to create settled villages and permanent agriculture was that the authorities in all periods recognised, as did residents, that permanent settlement meant deforestation and soil degradation. Whatever the outcome of villagisation might be, it was most unlikely to be improved agricultural productivity.

\section{Making Agriculture Pay}

The creation of the rural world in the first sixty years of the twentieth century involved an imaginative engagement with people, land and livelihoods that gave rise to a series of material consequences. Landscapes had to be settled with villages and villages had to be inhabited by rural dwellers who were farmers. Smallholder agriculture was characterised as backward and it needed to be replaced by more efficient agriculture. The colonial challenge, which post-colonial governments inherited, was how to make agriculture pay. The solution to this challenge was, in part, the improved farmer. He (and it was a man) would not only maintain the character of modern life, but he would also make agriculture productive. The authorities had been engaged from the 1950s onwards - and sometimes much earlier - in the production of someone called an improved farmer who would be an improvement on the subsistence farmer (Gertzel 2008; Moore and Vaughan 1994, 110139; Vickery 1986). The colonial notion of a progressive farmer in the northern province of Zambia implied a rejection of 'backward' shifting agriculture and a commitment to full-time, settled agriculture. It carried with it assumptions about lifestyle that went beyond ways of working the land to encompass a series of transformations. A progressive farmer was a man who would wish to separate himself from kin networks, build a decent brick house, educate his children, and be modern without being urbanised. His wife would be keen to learn the rudiments of domestic science. However, progressive famers themselves often had other agendas because becoming a farmer was an indication of wealth and a sign of status, and progressive farming was often a form of conspicuous consumption rather than a source of accumulation. It therefore required access to offfarm income and the management of multiple strategies for household reproduction. In the 1950s, very few people could rely on agricultural production alone (Moore and Vaughan 1994, 115-116), and this is a situation that has persisted up to the present day. The uncertain nature not just of government policy and broken promises, but of risky 
input supply, poor transport and weak guarantees of a market meant that peasant farmers in the Northern Province continued and continue to engage with shifting cultivation in order to guarantee food supplies, manage cropping patterns and labour requirements, and diversify risks (Grogan, Birch-Thomsen and Lyimo 2013). More importantly, investing in social networks to secure access to productive resources and to labour has remained crucial, and has continued to depend on membership in descent groups, as well as broader kin and non-kin networks (Berry 1993, 136-159).

In the valley areas of Elgeyo-Marakwet, membership in descent groups allowed famers and households to benefit from the distributive effects of different ecological zones. After Independence in 1963, restrictions on movement and settlement were lifted, and many men left to clear lands in the fertile forested areas of the Cherangani highlands (Cappon et al. 1985). Land also became available from the former white settler farms in Uasin Gishu and Trans Nzoia, and individuals most often acquired title to these lands through kinship links with family members employed by the government or parastatals. The postcolonial government, like the colonial government before it, wanted to reward followers and create loyal rural residents. Many men established second households in the Cherangani and made good use of the different cropping patterns, labour regimes and soils to diversify risk and gain access to commercial markets in the better served highlands. Exchange of goods between households in the valley and highlands was a common and regular feature of life, with maize and potatoes moving downwards to households and markets, and fruit and millet moving in the other direction. These exchange systems diversified consumption patterns, and research conducted in the valley area in the 1980s showed very clear processes of rural differentiation emerging between households who had secured access to land under title in the highlands and those who remained only with access to customary land in the valley. This process of differentiation accelerated from the 1970s onwards, as households in the highlands gained better access to education and urban wage opportunities. Differential access to land and other resources deepened social differentiation along lines of gender, generation and even within lineages.

Cultivation in the valley was itself ecologically diverse, making use of a communally maintained system of irrigation canals to cultivate individual household plots near the foot of the escarpment, as well as communally cleared clan lands further into the valley floor, and small scale plots of fruits and vegetables around the households on the escarpment side itself (Davies, Kiprutto and Moore 2014). From the 1930s onwards, cash came from selling fruits, animal skins, honey, tobacco and vegetables. Sweet potatoes, bananas and other fruit could be sold or bartered for food stuffs from the highlands, as was common when I started work in Tot Division in the valley in 1980. Food production has historically been variable, and low yields leave little room for manoeuvre when things go wrong. In 2008, a study in the same area found that in order to counter act food shortages, $43 \%$ of respondents engaged in casual labour, $10.87 \%$ sold cash crops, $10 \%$ purchased staple cereals from the market, $3.04 \%$ borrowed food, $4.35 \%$ sought relief food and 28.7\% sold animals (Kipkorir and Kareithi 2013, 19). A series of Government and NGO backed initiatives to improve agricultural production have been proposed, sputtered into life and extinguished again, partly as a result of lack of infrastructural support and state investment, and partly because of the remoteness of the area. However, while the agricultural system has been resilient, adapting to population growth and climate change, it has never produced sufficient income to drive long term intensification and agrarian transformation (Davies and Moore 2016). It has survived 
through diversification of social networks, ecological zones and sources of income. More than $68 \%$ of all Kenyan households are involved in agriculture, and the mean size of agricultural holdings is roughly 1 hectare - larger than in many other Sub-Saharan Africa countries (FAO 2014). But, land is an increasingly constraining factor of production for a sizeable and growing proportion of Kenya's population and rising population is associated with shrinking farm sizes. This is contributing to land intensification which does appear to increase the net value of crop production up to densities of about 550-600 persons/km2 (Muyanga and Jayne 2014, 103). Increased cash inputs and higher valued crops are observable forms of sustainable intensification under such conditions, but forms of intensification that are not sustainable include continuous cultivation and reductions in fallows without soil restoration (Powlson et al. 2011). This is evident from the fact that agricultural labour productivity does not rise with population density in a linear way, and above 550-600 persons/km2 the net value of crop output per labour unit declines. This is likely the result of soil degradation. Smaller farm sizes may also impede surplus production which in turn will impact on the financing of cash input purchases associated with land intensification. With declining land availability, increasing soil degradation and uncertain yields, the best prospect for these households could involve being pulled off land into non-farm sectors. However, findings from Kenya show that off-farm incomes are not increasing significantly, with large numbers of people working in petty trading in the informal sector and casual agricultural labour. These fragile non-farm/informal sectors cannot absorb the excess rural labour generated by declining land availability and productivity (Muyanga and Jayne 2014, 110).

Research conducted in 22 districts in Kenya in the period 1997-2007 found that only a small fraction of households experienced an appreciable improvement or decline in their relative asset wealth over that timeframe. Households that did transit out of poverty were those that remained healthy, were not adversely affected by mortality, received more land from their parents when the household was formed, and had parents who were relatively well-off and educated. Illness, death and minimal access to land undermined those households reporting declining prosperity. In such circumstances female-headed households were disadvantaged largely as a consequence of women's insecure access to land and inherited assets, as well as their reduced receipt of human capital investment, notably education and health (Muyanga, Jayne, and Burke 2013, 29-31).

Increasing population growth and land consolidation are driving agrarian change, but research from Kenya and Zambia suggests that this is not following a unilinear model of agrarian transformation and is not based on successful accumulation by small-scale farmers, throwing doubt on the idea that agricultural growth can effectively reduce rural poverty. However, if we look to recent drivers of change we see that between 2001-11, Zambia did see a rapid increase in 'emergent' famers with land holdings between 5-20 hectares. An analysis of the historical trajectory through which these farmers achieved their scale of operation revealed that this was supported by significant state investment in input and output (price) subsidies for maize, and by settlement schemes and land legislation permitting the legal conversion of customary land to leasehold title (Land Act 1995) (Sitko and Jayne, 2014, 196-197). 73\% of the farmers sampled in the research achieved emergent farmer status through financing from off-farm income, principally from public sector employment. The larger land holdings are concentrated among those with title to their land acquired after the 1995 Land Act. This is linked to state patronage where farmers are given land primarily through settlement schemes as a reward for public service. From the early 2000s, Zambia experienced a recovery in global copper prices 
and between 2005-15 sustained GDP growth rates of over 5\% this further increased opportunities for the urban employed to invest in agriculture, buoyed up by enabling land legislation and supportive public spending on larger farms (Sitko and Jayne, 2014, 198199).1 Curiously, however, respondents operating on titled land cultivate on average less than $30 \%$ of their land, in marked contrast to the overall smallholder population where $87.3 \%$ of all available land is cultivated (only $3 \%$ of Zambian smallholders own 6ha of land or more). Taking the requirements of fallow into account, this under utilisation of land means that the employment affect per hectare on emergent farms is limited, and that land consolidation and peasantisation are not creating sustainable forms of agricultural productivity nor a substantial agricultural labour market. In fact, those holding larger areas of land are utilising just a fraction of it for agricultural purposes. This suggests that state support for emergent farmers and land distribution are at the expense of poorer farmers, and are not driving large scale agrarian transformation (Sitko and Jayne, 2014, 200-201).

\section{Rural-Urban Connections}

The long quest for prosperity understood as enhanced agricultural productivity has taken a variety of historical turns, but what is clear is that the urban, whether in terms of formal sector employment, retirement pensions, aspiration or knowledge networks, has fundamentally shaped rural locales and environments. It is widely recognised that ruralurban migration is part and parcel of Africa rural life, and that migration is complementary to cultivation, rather than an alternative. The history of rural-urban migration in Kenya is a long one and the urban share of population has grown from $7 \%$ in 1960 to around 32\% today (KNBS 2009; World Bank 2007). However, while some research suggests that migration has changed its character over time from a predominantly circulatory form to one which is more pluralist, hybrid and translocal (Greiner and Sakdapolrak 2013a), there is no clear unilinear trajectory. The importance of translocality and plurality across -urban-rural divides was noted from the early 1970s in Kenya (Weisner 1976), where the importance of socialities that stretch across the different locales has always been key. James Ferguson has argued for Zambia that there has been no unilinear historical development in terms of types of migration, rather individual women and men have always pursued a variety of strategic alternatives to make use of the opportunities provided by the rural-urban division (1990, 411-412). Migration is rarely an individual or one-off decision, rural and urban family members in multi-locational households - those spread across rural-urban locales - have a say in who migrates and for how long (Agesa and Kim 2001; Greiner and Sakdapolrak 2013b). Over a third of all Kenyan households divide their members between rural and urban homes, and more than $80 \%$ of urban residents report maintaining strong connection with their rural kin (Agesa 2004). Migration, and the resulting remittances, are a household risk mitigation strategy, especially under conditions of environmental stress and land shortage, and transfers of income, goods and services have long been recognised as key 1 Since, 2016, the Zambian economy has slowed markedly again with exposure to reduced copper prices. World Bank. 2017. "The World Bank in Zambia." October 12. http://www.worldbank.org/en/country/zambia/overview to household survival. The unidirectional nature of these flows has been interrogated by extensive research which emphasises that with declining employment opportunities in urban areas and weaknesses in state safety net systems, reverse transfers are flowing from urban to rural contexts, with evidence for increasing urban-rural return migration (Djurfeldt and Wambugu 2011; Falkingham, Chepngeno-Langat, and Evandrou 2012; Owuor 2006, 2007), and even in some cases a stalling of urban growth (Beauchemin 2011; Potts 2010). 
Many migrants and long term urban residents - some of whom have never lived in the rural areas - claim that the farm is their real home, and that they wish to retire there and be buried there (Ferguson 2013; Geschiere 2014). Rural transformations are therefore bound up not only with essential urban linkages, but land and access to land are linked to forms of identity and belonging for rural and urban residents alike, as well as livelihoods (Gugler 2002; Shipton 2009). It is therefore increasingly difficult in contemporary Africa to divide the rural from the urban, either experientially, emotionally, analytically or economically (Losch, Magrin, and Imbernon 2013). Ferguson has recently argued persuasively that land in rural areas has to be seen not just - or even primarily - as a productive resource in the context of rural impoverishment and fragile livelihoods, but also as a space for leisure, comfort, connection and burial (Ferguson 2013). In other words, as a resource for the imagination, as well as a practical investment for those who are urban rather than rural residents. There is no strict rural/urban divide in Kenya, but there are certainly differences structured by outlook, opportunity, geographic mobility and effective action spaces.

In Kenya, issues of financial inclusion, investment, information transfer and social networks are being transformed by the technology of the mobile phone. When mobile phones first came in, an important driver of phone ownership initially was access to nonfarm income, but the cost of handsets and calls has fallen dramatically in the last 5 years. The Communications Authority of Kenya's 2015 report records 37.8 million mobile subscriptions in Kenya, with mobile penetration at $88.1 \%$ of the population. Total internet subscriptions are 21.6 million, with an estimated number of internet users of 31.9 million which is $74.2 \%$ of the population (CAK 2015). While they are personal - handsets have individual owners - the devices are also communal and shared, so that handsets help maintain social networks through exchange networks that involve the handset itself, as well as the information it conveys (Komen 2014).2 Managing multilocational households in Kenya is an intricate process, often happening over large distances. Phones clearly help spouses coordinate farm, household, and community activities (Oduor et al. 2014). In Elgeyo-Marakwet, personal calls merge greetings and staying in touch, with requests for seeds, help to prepare land and money to pay children's school fees. Implied in the Marakwet phrase 'takwessa tokol' (greet everyone) is a range of information about prices, politics, births, marriages and deaths that forms the real basis of exchanges dependent on labour, capital and knowledge, as well as the networks they create and 2 In the rural areas, ownership is still differentiated by gender and for women without a handset, borrowing from friends or family is the most common way to gain access to a phone (Murphy and Priebe 2011; Oduor et al. 2014, 2711) reproduce (Oduor et al. 2014, 2709). Studies elsewhere in Kenya show that $70 \%$ of women normally call siblings or other natal relatives, twice the rate for men (36\%), providing those married in patrilineal, virilocal societies with access to expanded networks of potential support and protection. Women in Marakwet also use mobiles to co-ordinate community activities, such as savings and Church groups. More men make long-distance calls for work, reaching pastors, church leaders, and government officials, farther away. The mobile phone links family members to their kinship and social networks, and onwards to larger networks of resource, influence and power (Jack, Ray, and Suri 2013; Jack and Suri 2014) This is key in the Kenyan context, where access to people is the surest route to gaining resources, education and even a job.

In contrast, to discussions around the relevance of mobile phones for development in Africa which focus on their potential to facilitate market transactions and economic 
growth, development projects, the communication of public health messages, and other technical means for addressing poverty, it is important to recognise that they perpetuate and expand an older strategy for survival based on investment in people. The mobile phone allows those resident outside the rural area to send money - via Mpesa the mobile phone money transfer system (Mbiti and Weil 2011; Morawczynski 2009) - to cut down the costs and time of travel, to make an input into agricultural and household decisions, and to offer advice and comfort, as well as to interfere! Those resident in the rural areas reap the same benefits through greater communication and connectivity. Together they are the new digital farmers of Kenya.

Land remains an important resource for people in Elgeyo-Marakwet. New ways of working the land emerge as people invest in the crops that new consumption patterns bring - tomatoes, onions, water melons, mangoes. Changing consumption patterns are linked to aspirations and ideas about the good life connected in people's imaginations with life 'in town'. Agrarian self-sufficiency is not a realistic option, since cash is needed to guarantee the satisfactions on which people rely for quality of life. Drawing on resources from kin settled in towns or on farms in the highlands, entrepreneurial activities, loans, and small-scale employment, those few who have resources are investing them in infrastructure - in roofed square houses, with water, solar powered electricity, televisions, sofa sets. They are also persuading the young men to cut basic roads through the steep, rocky areas in which the settlements sit. They are investing in expensive church weddings, moving around on motor bikes, eating bread and water melon. Class divisions are becoming very apparent, and are driven by differential access to land and cash. Many smallholders are sinking into bare subsistence, but since rural locales are spaces where complex repertoires of economic activity are played out through both farm and non-farm activity, issues of quality of life are being shaped by changing aspirations and consumption patterns, even for those households for whom they remain resolutely out of reach. The character of the rural is changing, but not because of improvements in agricultural productivity or accelerated agrarian transformation. There is less and less need to go to town - although everyone still does - because the village is becoming more like the town. The rural is beginning to have the same leisure facilities, comforts and entertainments of the town. And, as the residents will tell you the food and water are better in the rural areas, there is no pollution, the quality of life is better. These comforts are not in any way excessive, but they are the comforts of home. The long-time absent, well-educated, formally employed professionals are all building large houses for their retirement, just as they hoped they would. But, they are not the people who have transformed the rural area - although some of their income and resources will definitely have circulated in circuitous ways through many people's pockets. The valley has been transformed by its long-term residents, by their aspirations for a good life in a rural area. Rural livelihoods are evolving, but they are not always or even primarily based on agriculture in the sense of the cultivation of staples, but on complex ecologies of knowledge, resource, time and place.

\section{Conclusion}

In this paper, I have suggested that understanding agrarian change and the evolution and persistence of particular ways of conceptualising it require a form of analytical history based on the longue durée. Braudel's original insistence that the longue durée is a methodological tool rather than a theory itself and that its purpose is to help us understand the present is particularly germane for rural life in Africa. For one thing, it provides an analytical structure that allows us to lay out and comprehend the frameworks 
used both to create and to manage the ongoing crisis of rural livelihoods and their failed prosperity. For another, it emphasises the material consequences of interventions and of the way successive generations of analysts and policy makers have repeatedly tried to mould the nature of rural transformation through the imposition of models that have indelibly marked its present with its past.

Looking afresh at the changing character of rural lives and livelihoods, it is clear that the sine qua non of survival in many rural African contexts is income diversification. Rural residents have responded and continue to respond to changes in market access, prices, state subsidies, global commodity prices, new technologies, new crops, digital inclusion, even on-line extension services for farmers. These resources have been, and continue to be, patchily distributed across rural landscapes in Kenya and Zambia, and significant inequalities between regions within individual countries are important, but what does emerge is a concerted effort to use social networks to knit together resources in innovative ways. Dichotomous The boundaries between the rural and the urban make little analytical sense, especially since urban growth seems stalled in many parts of SubSaharan agriculture and employment opportunities have failed to keep pace with demographic change. Getting an education and going to town are no longer the real or imagined road to prosperity. The result is that the visions of African agrarian transformation espoused to varying degrees by rulers, residents and researchers have failed to live up to any sustained or sustainable model of unilinear development, whether based on agricultural intensification, educational opportunity, urbanisation or industrialisation. Rural residents have responded and continue to respond to changes in market access, prices, state subsidies, global commodity prices, new technologies, new crops, digital inclusion, even on-line extension services for farmers. These resources have been, and continue to be, patchily distributed across rural landscapes in Kenya and Zambia, and significant inequalities between regions within countries are important, but what does emerge is a concerted effort to use social networks to knit together resources in innovative ways.

This is a far cry from the visions of prosperous peasant farmers and rising agricultural productivity and incomes envisaged in various 5 year plans and development visions over the long decades of the twentieth century. There is no doubt that rising populations and declining size of landholdings, combined with reversals of agricultural policies, failure to reform land acquisition and registration, the erratic nature of the world economy, and the deepening ecological crisis of rising temperatures and acidifying soils are all working against the vision of an African agriculture that would not only support rural populations, but engage with export trade and raise government incomes. There is much to be said for the argument that the ongoing crisis of rural Africa is not the product of farmer resistance - whether this be figured as tradition, lack of productivity, lack of market integration etc. - but of a series of futures only equivocally offered, a failure to envisage what prosperity might mean and entail for Africa on its own terms and through the visions of its citizens. Growth rates in many Sub-Saharan countries have been solid in the last ten years, and there have been marked improvements also in maternal and child health, in transport infrastructures, in educational attainment, and in communication technologies. But, overall improvements in quality of life for most rural residents - the prosperity gain from such growth has been very minimal. We live in an age that is fully aware that its fictions are themselves models of human design on the world. Small-scale African farmers take this as pretty much axiomatic, and continue to seek prosperity through the complex forms of ecology, resource, capital and place that are based on social relations in 
an effort to mitigate the consequences of others' designs and to try and advance their own whenever opportunity arises.

\section{Bibliography}

Adam, C. S., P. Collier, and M. Gondwe, eds. 2014. Zambia: Building Prosperity from

Resource Wealth. Oxford: Oxford University Press.

Adam, C. S., P. Collier, and N. Ndung'u, eds. 2011. Kenya: Policies for Prosperity. Oxford: Oxford University Press.

Agesa, R. 2004. "One family, two households: rural to urban migration in Kenya."

Review of Economics of the Household 2 (2): 161-178.

Agesa, R., and S. Kim. 2001. "Rural to urban migration as a household decision: evidence from Kenya." Review of Development Economics 5 (1): 60-75.

Barrett, C. B. 2008. "Smallholder market participation: Concepts and evidence from eastern and southern Africa." Food Policy 33 (4): 299-317.

Beauchemin, C. 2011. "Rural-urban migration in West Africa: towards a reversal? Migration trends and economic situation in Burkina Faso and Côte d'Ivoire." Population, Space and Place 17 (1): 47-72.

Bernstein, H. 1979. "African peasantries: A theoretical framework." The Journal of Peasant Studies 6 (4): 421-443.

Berry, S. 1993. No Condition Is Permanent: The Social Dynamics of Agrarian Change in Sub-Saharan Africa. Wisconsin: Wisconsin University Press.

Bratton, M. 1980 The Local Politics of Rural Development: Peasant and Party-State in Zambia. Hanover, New Hampshire: University Press of New England

Braudel, F. (1949) 1995. The Mediterranean and the Mediterranean World in the Age of Philip II. 2 vols. Berkeley: University of California Press.

Braudel, F. (1958) 2009. "History and the Social Sciences: the Longue Durée." Review 32 (2): 171-203.

Bryceson, D. F. 2000. "African Peasants' Centrality and Marginality: Rural Labour Transformations." In Disappearing Peasantries: Rural Labour in Africa, Asia and Latin America, edited by D. F. Bryceson, C. Kay, and J. E. Mooij, 37-63. London: IT Publications.

CAK. 2015. First quarter sector statistics report for the financial year 2015/2016.

Nairobi: Communications Authority of Kenya.

Cappon, J., M. van den Goorbergh, M. Mwangi, and C. Saina. 1985. District Atlas Elgeyo Marakwet. Iten: Ministry of Planning and National Development, Kenya.

Cliggett, L. 2000. "Social components of migration: experiences from Southern Province, Zambia." Human Organization 59 (1): 125-135.

Cliggett, L. 2001. "Survival strategies of the elderly in Gwembe Valley, Zambia: Gender, residence and kin networks." Journal of Cross-Cultural Gerontology 16 (4): 309-332.

Cliggett, L., E. Colson, R. Hay, T. Scudder, J. Unruh. 2007. "Chronic uncertainty and momentary opportunity: A half century of adaptation among Zambia's Gwembe Tonga." Human Ecology 35 (1): 19-31.

Davies, M., and H.L. Moore. 2016. "Landscape, time and cultural resilience: a brief history of the agricultural Pokot and Marakwet." Journal of Eastern African Studies 10 (1): 67-87.

Davies, M., Kiprutto, T., and H.L. Moore 2014 "Revisiting the irrigated agricultural landscape of the Marakwet, Kenya: tracing local technology and knowledge over the recent past". Azania 49 (4):486-523

Djurfeldt, A., and S. Wambugu. 2011. "In-kind transfers of maize, commercialization and household consumption in Kenya." Journal of Eastern African Studies 5(3): 447-464. 
Duncombe, R. 2014. "Understanding the Impact of Mobile Phones on Livelihoods in Developing Countries." Development Policy Review 32 (5): 567-588.

Falkingham, J., G. Chepngeno-Langat, and M. Evandrou. 2012. "Outward migration from large cities: are older migrants in Nairobi 'returning'?" Population, Space and Place 18 (3): 327-343.

Fallers, L. 1961. "Are African cultivators to be called "Peasants"?” Current Anthropology 2 (2): 108-110.

FAO, 2014. The state of food and agriculture: innovation in family farming. Rome: Food and Agriculture Organisation.

Ferguson, J. 2013. "How to do things with land: A distributive perspective on rural livelihoods in Southern Africa." Journal of agrarian change 13(1): 166-174.

Ferguson, J. 1990 "Mobile workers, modernist narratives: a critique of the historiography of transition on the Zambian Copperbelt [part one]". Journal of Southern African Studies. 16(3): 385-412

Fioramonti, L. 2017. The World After GDP: Politics, Business and Society in the Post Growth Era. Cambridge: Polity Press

Gertzel, C. 2008. "East and Central Africa." In The Cambridge History of Africa Vol. 8, edited by M. Crowder, 383-457. Cambridge: Cambridge University Press.

Geschiere, P. 2014. "The Funeral in the Village: Urbanites' Shifting Imaginations of Belonging, Mobility, and Community." In The Arts of Citizenship in African Cities, edited by M. Diouf and R. Fredericks, 49-66. New York: Palgrave Macmillan.

Greiner, C., and P. Sakdapolrak. 2013a. "Rural-urban migration, agrarian change, and the environment in Kenya: a critical review of the literature." Population and Environment 34 (4): 524-553

Greiner, C., and P. Sakdapolrak. 2013b. "Translocality: Concepts, applications and emerging research perspectives." Geography Compass 7 (5): 373-384.

Gugler, J. 2002. "The son of the hawk does not remain abroad: the urban-rural connection in Africa." African Studies Review 45 (1): 21-41.

Hepburn, C., E. Beinhocker, J. D. Farmer, and A. Teytelboym. 2014. "Resilient and Inclusive Prosperity within Planetary Boundaries". China and World Economy 22 (5): 76-92.

Isaacman, A. 1990. "Peasants and rural social protest in Africa." African Studies Review 33 (2): 1-120.

Jack, W., and T. Suri. 2014. "Risk Sharing and Transactions Costs: Evidence from Kenya’s Mobile Money Revolution.” American Economic Review 104 (1): 183-223. Jack, W., A. Ray, and T. Suri. 2013. "Transaction Networks: Evidence from Mobile Money in Kenya." American Economic Review 103 (3): 356-361.

Jackson, T. 2017 Prosperity Without Growth: Foundations for the Economy of Tomorrow. 2nd edition. New York, NY: Routledge

Jameson, F. 1991. Postmodernism or the Cultural Logic of Late Capitalism. London: Verso.

Kermode, F. 2000. The Sense of an Ending. Oxford: Oxford University Press.

Kikulwe, E., E. Fischer, and M. Qaim. 2014. "Mobile money, smallholder farmers, and household welfare in Kenya." PloS ONE 9 (10): 1-13.

Kipkorir, D., and J. Kareithi. 2013. "Indigenous Irrigation and Food Security in Tot Division, Kerio Valley, Kenya.” Journal of Anthropology \& Archaeology 1 (1): 12-27. Kirui, O., J. Okello, R. Nyikal, and G. Njiraini. 2013. "Impact of mobile phone-based money transfer services in agriculture: evidence from Kenya." Quarterly Journal of International Agriculture 52 (2): 141-162.

L Komen 2014 Mobile Assemblages and Maendeleo in Rural Kenya: The Case of 
Marakwet. PhD thesis, University of East London.

KNBS. 2009. Kenya Census 2009. Nairobi: Kenya National Bureau of Statistics. Kusimba, S.,Y. Yang, and N. Chawla. 2015. "Family networks of mobile money in Kenya." Information Technologies \& International Development 11 (3):1-21.

Kusimba, S., H. Chaggar, E. Gross, and G. Kunyu. 2013. "Social networks of mobile money in Kenya." Working Paper. Irvine, CA: University of California, Institute of Mobile Money, Technology and Financial Inclusion.

Latour, B. 1993. We Have Never Been Modern. Cambridge, MA: Harvard University Press.

Losch, B., G. Magrin, and J. Imbernon. 2013. A New Emerging Rural World. An Overview of Rural Change in Africa. Montpellier: CIRAD.

Mbiti, I. M., and D. Weil. 2011. "Mobile banking: the impact of M-Pesa in Kenya NBER working paper No. 17129." Cambridge MA: National Bureau of Economic Research. Moore, H. L. 1996. Space, Text and Gender: An Anthropological Study of Marakwet of Kenya. 2nd ed. New York: Guilford.

Moore, H. L. 2011. Still Life: Hopes, Desires and Satisfactions. Cambridge: Polity Press. Moore, H. L. 2015. "Global Prosperity and Sustainable Development Goals". Journal of International Development 27 (6): 801-15.

Moore, H. L., and M. Vaughan. 1994. Cutting Down Trees: Gender, Nutrition and Change in the Northern Province of Zambia, 1890-1990. Portsmouth, NH: Heinneman. Moore, H.L., and S. Woodcraft. 2018 "Placing sustainable prosperity in East London: local meanings and 'sticky' measures of the good life". City and Society. Forthcoming Morawczynski, O. 2009. "Exploring the usage and impact of 'transformational' mobile financial services: the case of M-Pesa in Kenya." Journal of Eastern African Studies 3 (3): 509-525.

Murphy, L., and A. Priebe. 2011. "My co-wife can borrow my mobile phone: gender geographies of cell phone usage and significance for rural Kenyans." Gender,

Technology and Development 15 (1): 1-23.

Muyanga, M., and T. Jayne. 2014. "Effects of rising population density on small holder agriculture in Kenya." Food Policy 48: 98-113

Muyanga, M., T. Jayne, and W. Burke. 2013. "Pathways into and out of poverty: A study of rural household wealth dynamics in Kenya." The Journal of Development Studies 49 (10): 1358-1374.

Nietzsche, F. 1968. The Will to Power. New York: Vintage.

Oduor, E., C. Neustaedter, T. Judge, K. Hennessy, C. Pang, and S. Hillman. 2014. "How technology supports family communication in rural, suburban, and urban Kenya." In Proceedings of the 32nd annual ACM conference on Human Factors in computing systems. Place: ACM.

OECD, 2017. OECD Better Life Index. Accessed January 15th 2018. http://www.oecdbetterlifeindex.org/\#/11111111111 Oucho, J. 2007. "Migration and regional development in Kenya." Development 50 (4): 88-93.

Owuor, S. 2006. Bridging the urban-rural divide: multi-spatial livelihoods in Nakuru town, Kenya. Leiden: African Studies Centre.

Owuor, S. 2007. "Migrants, urban poverty and the changing nature of urban-rural linkages in Kenya." Development Southern Africa 24 (1): 109-122.

Philipsen, D. 2017. The Little Big Number: How GDP Came to Rule the World and What to Do about It. Princeton: Princeton University Press.

Polanyi, K. 1944. The great transformation. The political and economic origins of our times. Boston: Beacon Press. 
Pollard, G., M. I. J. Davies, and, H. L. Moore. 2015. "Women, marketplaces and exchange partners amongst the Marakwet of northwest Kenya." Journal of Eastern African Studies 9 (3): 412-439.

Potts, D. 2005. "Counter urbanization on the Zambian Copperbelt? Interpretations and Implications." Urban Studies 42 (4): 583-609.

Potts, D. 2010. Circular migration in Zimbabwe \& contemporary sub-Saharan Africa. London: James Currey.

Powlson, D.S., P.J. Gregory, W.R. Whalley, J.N. Quinton, D.W. Hopkins, A.P. Whitmore, P.R. Hirsch, and K.W.T. Goulding. 2011. "Soil management in relation to sustainable agriculture and ecosystem services." Food Policy 36, Supplement 1:S72-S87. Richards, A. 1939. Land, Labour and Diet in Northern Rhodesia: An Economic Study of the Bemba Tribe. Oxford: Oxford University Press.

Shipton, P. 2009. Mortgaging the Ancestors: Ideologies of attachment in Africa. New Haven: Yale University Press.

Sitko, N., and T. Jayne. 2014. "Structural transformation or elite land capture? The growth of 'emergent' farmers in Zambia." Food Policy 48: 194-202.

Smith, C. D. 1989. "Did Colonialism capture the peasantry? A case study of the Kagera District, Tanzania.” Research Report 83. Uppsala: Scandinavian Institute of African Studies.

Social Progress Index. 2017. Social Progress Imperative. Accessed January 15th 2018. http://www.socialprogressimperative.org/global-index/.

Tembo, R. 2010. "Money, Conflict and Reciprocity in Rural Families in Zambia: The Case of Female University Students." Working Paper. Irvine: The Institute for Money, Technology, and Financial Inclusion, University of California.

Turner, V. 1972. Schism and Continuity in an Africa Society: A Study of Ndembu Village Life. Place of publication?: Manchester University Press.

Valbuena, D., J. Groot, J. Mukalama, B. Gérard, and P. Tittonell. 2015. "Improving rural livelihoods as a "moving target": trajectories of change in smallholder farming systems of Western Kenya." Regional Environmental Change 15 (7): 1395-1407.

Vickery, K. 1986. Black and White in Southern Zambia: The Tonga Plateau Economy and British Imperialism 1890-1939. Westport, CT: Praeger.

Weisner, T. 1976. "The structure of sociability: Urban migration and urban-rural ties in Kenya." Urban Anthropology 5 (2): 199-223.

Welch, C. 1977. "Peasants as a Focus in African Studies." African Studies Review 20 (3): $1-5$.

Whitehead, A. N. 1967. Adventures of Ideas. Free Press: New York.

World Bank. 2007. World Development Report 2008: Agriculture for development.

Washington: World Bank.

World Bank. 2016. Kenya Country Economic Memorandum: From Economic Growth to Jobs and Shared Prosperity. Accessed January 15th 2018 Accessed Month Date Year. http://documents.worldbank.org/curated/en/763771468197384854/pdf/103822-WPKenyaCountry-Economic-Memorandum-PUBLIC.pdf 